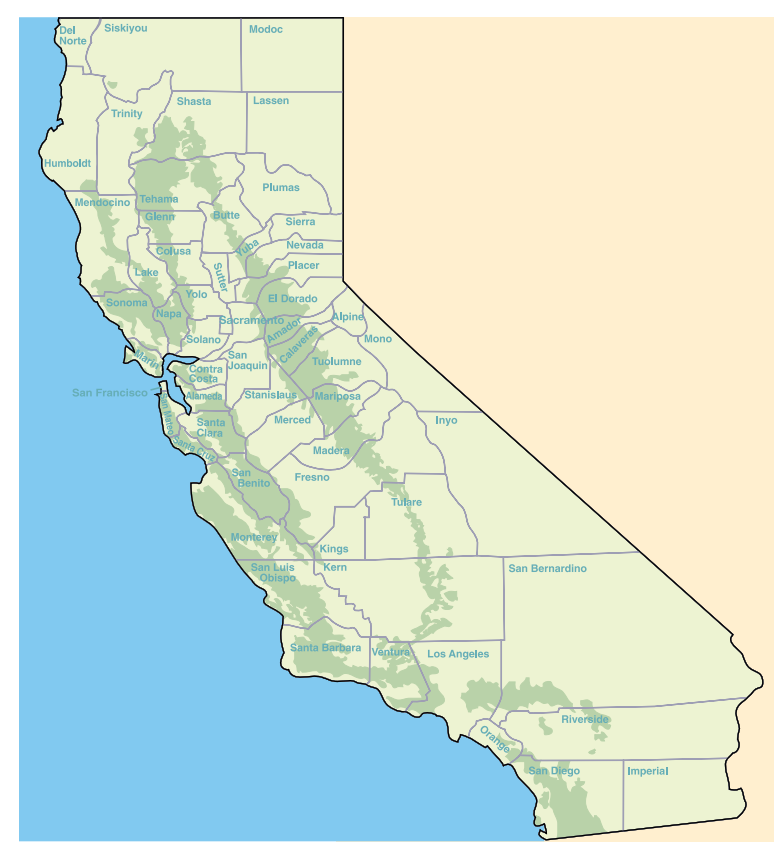

Distribution of oak woodlands and forests in California (shaded area). Source: Allen-Diaz B, Standiford R, Jackson RD. 2007 (in press). In: Terrestrial Vegetation of California. Berkeley, CA: UC Press.

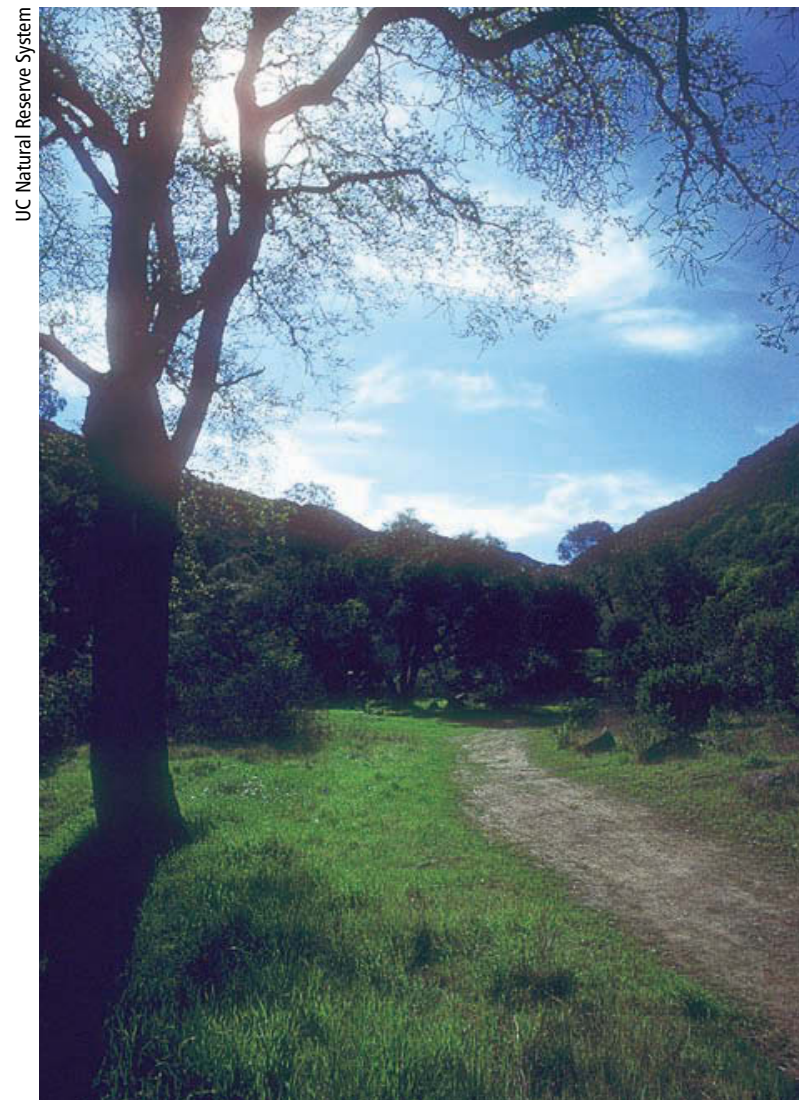

California's 10 million acres of oak woodlands are threatened primarily by land conversions to intensive agriculture and housing, and poor regeneration. Researchers can study oak habitat at the UC Natural Reserve System's Stebbins Cold Canyon Reserve in Solano and Napa counties.

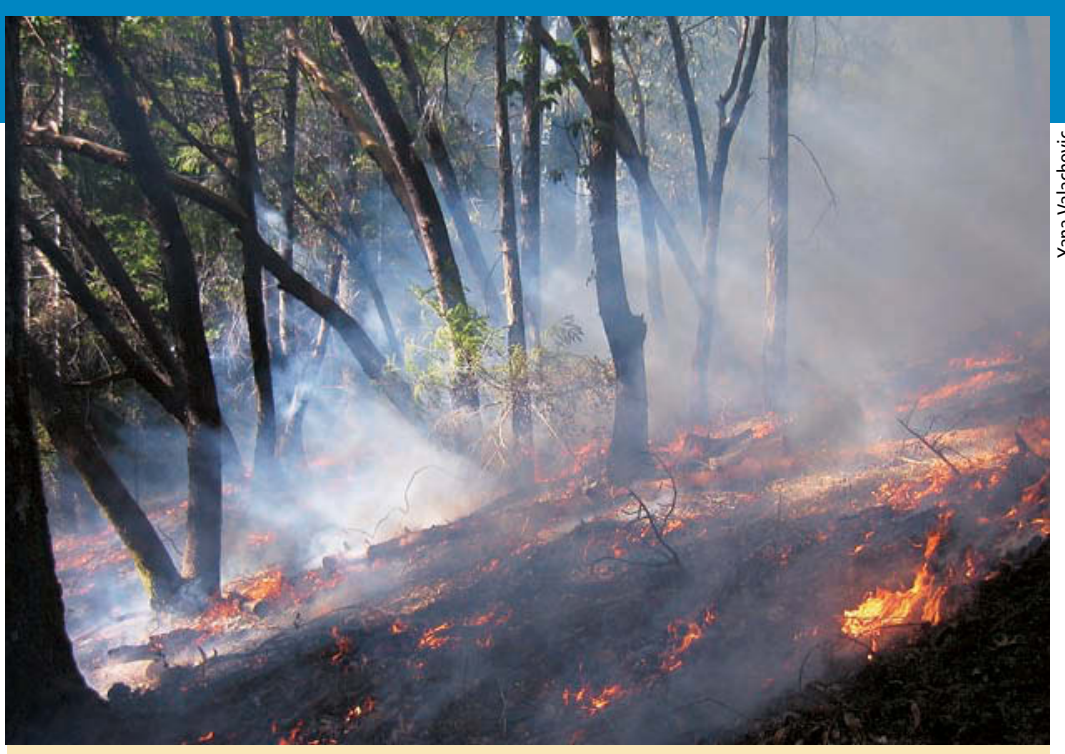

A controlled fire in Humboldt County helps remove contaminated leaf litter.

\section{Treatments could slow spread of sudden oak death}

UC Cooperative Extension (UCCE) researchers are now testing new treatments that may help keep sudden oak death from spreading. First detected in California in 1995, the pathogen (Phytophthora ramorum) that causes this disease now infests 14 coastal counties and has killed more than a million native oaks and tanoaks. While experts acknowledge that there is little chance of eradicating sudden oak death where it is well established, there is still hope for stopping new infestations.

"We have to learn to live with this disease," says project leader Yana Valachovic, UCCE forest advisor for Humboldt and Del Norte counties. "Our goals are strategic containment and developing long-term management options for landowners." Her collaborators include the USDA Forest Service, California State Parks and the California Department of Forestry and Fire Protection.

In early 2006, the team began testing treatments in four forested areas totalling 140 acres in Humboldt County, the state's northern limit of sudden oak death. The treatments include:

- Cutting infected tanoaks and bay laurels, which are the species most likely to spread the disease, and burning the infectious twigs and leaves on-site.

- Using herbicides to prevent cut trees from resprouting as well as to kill infected trees.

- Treating healthy oaks with the fungicide Agri-Fos, which can protect against infection.

- Using controlled fire to consume infected leaf litter and other plant material on the ground.

To find the best combination of treatments, the team will evaluate them over a number of years. The evaluation measures include whether the pathogen appears in new vegetation such as seedlings and sprouts from cut trees, how much the treatments cost and public attitudes toward them. Valachovic will present the team's initial results in March 2007 at the Third Sudden Oak Death Science Symposium (http:/ / nature.berkeley.edu/comtf/sodsymposium), which is sponsored in part by the UC Integrated Hardwood Range Management Program.

- Robin Meadows 